DOI: https://doi.org/10.34069/AI/2022.49.01.21 How to Cite:

Cherneha, V., Bohdanets, A., \& Kononets, O. (2022). Forms and ways of defending family rights and interests in Ukraine. Amazonia Investiga, 11(49), 189-197. https://doi.org/10.34069/AI/2022.49.01.21

\title{
Forms and ways of defending family rights and interests in Ukraine
}

\section{Форми та способи захисту сімейних прав та інтересів в Україні}

Received: November 28, 2021

Accepted: January 15, 2022

\begin{abstract}
This study taps the potential of forms of defence of family rights and interests in Ukraine. It speaks in favour of the establishment of the Family Court in Ukraine by adopting the best foreign practices. It also presents an updated systematics in terms of ways to defend family rights and interests and contains the amendments to the Family and Civil Codes of Ukraine to harmonize family law terms with civil law ones, improve them and correctly name the ways of defending family and civil rights and interests. It points at and offers to remove legal impediments that prevent the extension of the limitation period in the case stipulated in Part 3, Article 138 of the Family Code of Ukraine. This study also seeks to show the existing problems and opportunities in terms of forms and ways of defending family rights and interests in Ukraine. For this end, the following methods of scientific inquiry have been used: analysis, analogy, deduction, induction, synthesis, historical, systematic, structural and functional, comparative, logical and semantic, formal and logical, modelling methods.
\end{abstract}

Keywords: defence of family rights and interests, family rights and interests, Family Court, ways to defend family rights and interests, forms of defence of family rights and interests.
Анотація

У статті розкрито потенціал форм захисту сімейних прав та інтересів в Україні. Враховуючи зарубіжний досвід, обстояно позицію про створення в Україні Суду в сімейних справах. Презентовано модернізовану систематику способів захисту сімейних прав та інтересів. Задля узгодження сімейно-правової та цивільно-правової термінології, іiі вдосконалення, а також для коректного пойменування способів захисту сімейних i цивільних прав та інтересів, сформовано зміни до Сімейного та Цивільного кодексів України. Виявлено та запропоновано усунути законодавчі перешкоди щодо продовження позовної давності у випадку, встановленому частиною 3 статті 138 Сімейного кодексу України. Метою дослідження $\epsilon$ розкриття проблем та потенціалу форм та способів захисту сімейних прав та інтересів в Україні. Для досягнення мети дослідження застосовано такі методи наукового пізнання: аналіз, аналогія, дедукція, індукція, синтез, історико-правовий, логіко-семантичний, системний, структурнофункціональний, порівняльно-правовий, формально-логічний, а також метод правового моделювання.

Ключові слова: захист сімейних прав та інтересів, сімейні права та інтереси, Суд у сімейних справах, способи захисту сімейних прав та інтересів, форми захисту сімейних прав та інтересів.

\footnotetext{
${ }^{83}$ Candidate of Science of Law, Docent, Associate Professor at the Department of Business Law and Corporate Law of the State Higher Educational Institution Kyiv National Economic University named after Vadym Hetman, Ukraine.

${ }^{84}$ Candidate of Science of Law, Associate Professor at the Department of Civil and Labor Law of the State Higher Educational Institution Kyiv National Economic University named after Vadym Hetman, Ukraine.

${ }^{85}$ Candidate of Science of Law, Associate Professor at the Department of International, Civil and Commercial Law of the Kyiv National University of Trade and Economics, Ukraine.
} 


\section{Introduction}

"The establishment, enforcement, and exercise of human rights are important indicators in a state showing that it is governed by the rule of law" (Matvieieva, Baltadzhy, Shmalenko, Yeftiieni, Ivanchenko, 2021). The defence of family rights and interests is one of fundamental problems addressed by the law theory and practice since acts on the defence of family rights and interests are central to the legal regulation of family relations. "Family obligations are not always duly fulfilled by everybody. It causes the need of a person concerned for the defence. The need for defence sometimes results from the collision of lawful interests of a wife and a husband, a child`s mother and father" (Romovska, 2009).

Even though there are legislative and doctrinal achievements in terms of forms and ways of defending family rights and interests, some problems remain outstanding. First, although the judicial defence of family rights and interests is one of wide-spread legal forms of defence of the abovementioned rights and interests, Ukraine has not implemented yet the best practices of foreign countries that successfully established special judicial institutions - family courts. Second, the systematization of ways to defend family rights and interests prescribed by the Ukrainian law needs to be updated. Third, the terms used (in legislation) to name the ways to defend family rights and interests in Ukraine require correction. Fourth, at present it is impossible for persons at law to extend the period set by Part 3 of Article 138 of the Family Code of Ukraine (Law No. 2947-III, 2002).

The research seeks to show problems and opportunities in terms of forms and ways of defending family rights and interests in Ukraine.

\section{Literature Review}

Forms and ways of defending family rights and interest were studied by law scholars and (or) practitioners including M. Diakovych (2020), I. Zhylinkova (2008), L. Krasytska (2015), Z. Romovska (2009), V. Truba (2021), H. Churpita (2020), I. Serdechna (2019) and others. However, to achieve the purpose of this research, their studies are not enough. Existing research of these scientists is not enough, which is this. The expediency of establishing family courts in Ukraine is not substantiated. The systemation of ways to defend family rights and interests prescribed by the Ukrainian law needs to be updated. The terms used (in legislation) to name the ways to defend family rights and interests in Ukraine require correction.

\section{Methodology}

When studying forms and ways used to defend family rights and interests in Ukraine, the following methods were directly employed: analysis, analogy, deduction, induction, synthesis etc. The historical method has allowed understanding how legal provisions establishing named ways to defend family rights and interests developed. The systematic method has helped determine the place of ways in the system of ways to defend family rights and interests. The structural and functional analysis has contributed to detecting functions of the ways to defend family rights and interests. The comparative method was used to determine common and different features of the ways of defending family and civil rights and interests and allowed finding differences between Ukrainian and foreign judicial practices in family matters. The logical and semantic method helped improve the terminology in accordance with the subject of research. Application of the formal and logical method has made it possible to understand the essence of legal categories described herein and make scientific arguments and conclusions in view of the subject of research. The modelling method allowed articulating specific offers to improve effective Ukrainian legislation through the lens of the ways used to defend family rights and interests and development of Ukrainian judicial machinery, inter alia, by establishing the Family Court. ** The legal basis for the study is the Constitution of Ukraine, the Family Code of Ukraine, the Civil Code of Ukraine, the Civil Procedure Code of Ukraine, the Law of Ukraine "On Amendments to Family and Civil Codes of Ukraine" and the Law of Ukraine "On Amending Certain Legislative Acts of Ukraine Aimed at Ensuring Additional Social and Economic Guarantees in Relation to Spreading of Coronavirus Disease (COVID-19)". The empirical component of the stady consists of the law enforcement materials, inter alia, the decisions of the Supreme Court.

\section{Results and Discussion}

Opportunities Seen in terms of Jurisdictional and Non-jurisdictional Forms of Defence of Family Rights and Interests. Jurisdictional forms of defence of family rights and interests include claims filed to a court, tutorship and 


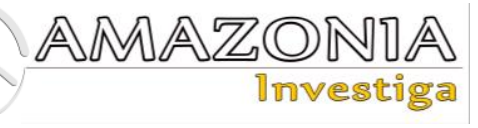

guardianship authority,

Children's

Commissioner, police etc.

Family rights and interests "are protected by different legal means among which a special place is occupied by judicial defence as it has the largest, compared with others, powers granted by legislators" (Churpita, 2020). The judicial defence is based on Articles 55, 124 of the Constitution of Ukraine (Law No. 254к/96-BP, 1996), Article 4 of the Civil Procedure Code of Ukraine granting each person the right to apply to a court for the defence of their rights, freedoms or lawful interests (Law No. 1618-IV, 2004).

Pursuant to Part 10, Article 7 of the Family Code of Ukraine, each party to family relations has the right to the judicial defence. It means that the exercise by a party to family relations of their subjective right also presupposes the defence of such a right. However, "a critical aspect of the practical implementation of the human right to access to justice is the proper organisation of the judicial branch of power" (M. Stefanchuk, Hladun, R. Stefanchuk, 2021a).

The tutorship and guardianship authority occupies an essential place in the system of jurisdictional forms of defence of family rights and interests. A person may file a preliminary request to it in cases stipulated by law. The preliminary defence of family rights and interests at tutorship and guardianship authorities "is implied when we refer to the assistance granted by the tutorship and guardianship authority" (Truba, 2021). Such a step precedes bringing the matter before the court.

For instance, Civil Registrar`s Office is entitled to fix judicially the paternity of the man who is not married to the child`s mother upon common request of the child's mother and father (Article 126 of the Family Code of Ukraine); reinstate the marriage if the person declared missing or presumed dead appears (Article 118 of the Family Code of Ukraine).

The analysis of family legislation allows stating that a notary defends family rights and interests by making a writ of execution. Pursuant to the Family Code of Ukraine, child-support payments may be collected by virtue of the notary writ of execution if:

one of spouses fails to fulfil their obligations stipulated in the child support agreement (Part 2, Article 78);

one of spouses fails to fulfil their obligations under the agreement (Part 2 Article 189).
The review of the Family Code of Ukraine allows concluding that some powers to defend relevant rights and interests are granted to the Prosecutor's Office. Thus, the abovementioned regulatory act entitles the prosecutor to file claims to the court for: finding a marriage invalid (Article 42); depriving of parental rights (Article 165);

taking a child away from his/her parents deprived of their parental rights (Article 170); cancelling adoption and finding it invalid (Article 240). In exceptional cases, a prosecutor may decide to immediately take a child away from his/her parents if the child's health or life is directly exposed to threat (Part 2, Article 170 of the Family Code of Ukraine).

Police enforces the decisions made to take a child away from his/her parents, finds persons who fail to pay child support and supervises activities of guardians and tutors.

The non-jurisdictional form of defence of family rights and interests covers actions taken by legal and physical entities to defend their rights on their own, i.e. without involvement of state or other agencies.

The family legislation grant parents the right to self-defence. For instance, Part 1, Article 154 of the Family Code of Ukraine, entitles parents to defend their children, daughters, sons of age on their own.

To see how a relevant right to self-defence is granted to a child, it is worth referring to Part 2, Article 152 of the Family Code of Ukraine where legislators mention this term as a remedy that may be used by a child to object to the improper fulfilment by his/her parents of their parental duties in relation to him/her.

The self-defence means active actions taken by an entitled party to family relations (including both a right holder and their parents, guardians, tutors, grandparents etc.) seeking to change or stop abusive practices of the other person involved in such an offence as prescribed by effective legislation (Diakovych, 2020).

Establishment of Family Court in Ukraine. Modern law scholars underline that one of tasks of the judicial reform in Ukraine is "to apply the best international justice standards, increase personal involvement in administration of justice, ensure the rule of law and effective protection of human rights, enhance public trust to courts and court decisions" (M. Stefanchuk, Hladun, R. Stefanchuk, 2021b). This should also 
apply to ensuring by law as effective defence of infringed, unrecognised, or disputed family rights and interests in a court as possible. That is why it is difficult to contest a statement that "family rights and interests are best defended in a court" (Serdechna, 2019).

In contrast to Ukraine with its current legislation on court organization, the important place in the court system organization charts of foreign countries including Australia, Great Britain, Israel, Canada, New Zealand, Singapore, the United States of America, the Federative Republic of Germany, Japan is held by family courts. By the way, 2018 saw the launch of the "Family Court" pilot project in Kazakhstan. This judicial body has different names in the abovementioned countries pertaining to different legal systems. The cases subject to the jurisdiction of such court also differ. Ukraine should establish the family court. Such a name will be the best to point at the jurisdiction of this judicial body. In the future, it should hear cases arising from family relations. The following family cases (disputes) should be considered within action proceedings:

giving a permission to take an underage child abroad; finding a family law agreement invalid;

establishing legal fatherhood or motherhood; bringing children back to the country of their permanent residence;

depriving of parental rights; dissolving a marriage;

collecting child-support payments.

Family cases to be heard within the writ proceedings are the following:

collecting child-support payments amounting to $1 / 4$ of the child support payer's earnings (income) for one child, $1 / 3$ - for two children, $1 / 2$ - for three children and more given that such an amount may not exceed 10 minimum wages for each child of an eligible age;

collecting child-support payments in hard cash which is $50 \%$ of a minimum wage for a child of an eligible age unless such a claim is connected with establishing or disputing legal fatherhood (motherhood).

Family cases (disputes) to be considered within special proceedings include the following:

establishing the reparation regime upon spouses' request;

granting the marriage right; dissolving the marriage upon request of spouses who have children;

dissolving the marriage upon request of spouses if one of spouses is sentenced to prison;

adoption by Ukrainian citizens who live abroad and foreigners; adoption by Ukrainian citizens who live in Ukraine;

establishing the fact that there are family ties between and among individuals;

establishing the facts of marriage registration, dissolution, adoption;

establishing the fact that a man and a woman are not married and live as a family.

Such a legislative decision in Ukraine should be based on available practices of similar courts in many foreign countries. On the one hand, it will help defend rights and interests of parties to family relations the best way possible, and on the other hand, it will allow finding optimal solutions in view of the specific procedures for considering and resolving family cases (disputes) in a court.

Problems in terms of Systematisation and Names Given to Ways of Defending Family Rights and Interests. Paragraph 2, Part 2, Article 18 of the Family Code of Ukraine as primarily worded sets forth a smaller number of ways to defend family right and interests. It covered, inter alia: the establishment of legal relationships; the enforcement of the obligation which was not fulfilled voluntarily; the prevention of actions which result in violation of family rights; the reinstatement of the legal relationship existing before the violation of a right; the compensation for financial and emotional damages in cases stipulated in the Family Code of Ukraine or an agreement.

Later, the abovementioned ways to defend family rights and interests became more numerous. Hance, the Law of Ukraine "On Amendments to Family and Civil Codes of Ukraine" dated 22 December 2006 supplemented Part 2, Article 18 of the Family Code of Ukraine with Paragraphs 7 and 8 which establish the following ways to defend family rights and interests: a) changing a legal relationship; b) finding decisions, actions or omission of a government agency, a government agency of the Autonomous Republic of Crimea or local government agency, their officials and officers illegal (Law No. 524-V, 2006). The studies seem to be fair when say that the abovementioned list of ways to defend family rights and interests prescribed by legislation is not exhaustive (Zhylinkova, 2008; Huz \& Huz, 2011; Krasytska, 2015). 


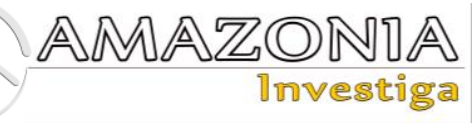

However, the existing wording of Paragraph 2, Part 2, Article 18 of the Family Code of Ukraine requires updating. First, it is necessary to eliminate differences between terms used in the Family and Civil Codes in Ukraine. The Family Code of Ukraine should substitute the term "financial damage" with "property damage" which is widely used not only by modern law scholars but also in modern regulatory materials (for example, in the Civil Code of Ukraine). It is obvious that this problem arose because the abovementioned codified acts were not adopted by the Parliament at the same time: the Family Code of Ukraine was adopted on 10 January 2002, and the Civil Code of Ukraine was adopted a year later, on 16 January 2003 (Law No. 435IV, 2003).

Moreover, the terms used to name ways to defend family and civil rights and interests in Clause 6 of the Family Code of Ukraine ("відикодування матеріальної та моральної икоди" (Eng: "paying financial and emotional damages")) and in Clauses 8 ("відикодування збитків" (Eng: "paying losses"), "відикодування майнової икоди" (Eng: "paying property damages")) and 9 ("відшкодування моральної (немайнової) цкоди" (Eng: "paying emotional (non-property) damages")) of Part 2, Article 16 of the Civil Code of Ukraine are not good enough. Experts should also revise the expressions used in the Special Part of the Family Code of Ukraine including: "відикодувати затрати" (Eng.: "to repay expenses") (Part 3, Article 31), "відикодувати вapmicmb peri" (Eng.: to recompense the cost of the thing") (Paragraph 2, Part 4, Article 31), "відикодування моральної икоди" (Eng.: "paying emotional damages") (Part 2, Article 49; Part 2, Article 50), "відшкодувати матеріальну та моральну икоду" (Eng.: "to pay financial and emotional damages") (Paragraph 2, Part 4, Article 157; Part 2, Article 158; Part 5, Article 159; Part 2, Article 162), "відикодувати матеріальну шкоду" (Eng.: "to pay financial damages") (Part 9, Article 177).

Similar terminological problems are seen in the Civil Code of Ukraine. First, we should mention Articles 22-23 of the Civil Code of Ukraine which subsidiarily apply to the legal regulation of family relations. It is incorrect from either philological or legal viewpoint to use the following expressions in the Civil Code of Ukraine: "відикодування збитків" (Eng.: "paying losses") (title of Article 22), "відикодування майнової шкоди" (Eng.: "paying property damages") (title of Article 22), "право на відикодування збитків" (Eng.: "right to payment of losses") (Part 1, Article 22), "збитки відшкодовуються" (Eng.: "losses are payable") (Paragraph 1, Part 3, Article 22), "розмір упущеної вигоди, що має відикодовуватися" (Eng.: "the amount of payable expectation damages") (Paragraph 2, Part 3, Article 22), "майнова шкода може бути відикодована" (Eng.: "property damages are payable") (Part 4, Article 22), "шкода завдана майну може відикодовуватися" (Eng.: damages to the property are payable) (Part 4, Article 22). Similar terminological imperfections may be also seen in other provisions of the Civil Code of Ukraine: "відшкодування моральної икоди" (Eng.: "paying emotional damages") (title of Article 23; Part 1, Article 23; Paragraph 2, Part 3, Article 23), "моральна шкода відикодовується" (Eng.: "emotional damages are payable") (Parts 3, 4, 5, Article 23). The other provisions of the Civil Code of Ukraine containing the abovementioned "terms" and their derivatives should also be amended.

The "conflict" may be resolved legally and philologically with the term "компенсація" (Eng.: "compensation") which has the Latin origin, i.e. it was used by Roman lawyers. The semantics of the word "compensation" allows concluding that "payment" is only one of its manifestations. Therefore, it is not reasonable to equate "компенсація" (Eng.: "compensation") with "відшкодування" (Eng.: "payment"). The term "compensation" should be used for scientific purposes by lawyers, and it should be used in any and all cases not only in the Family and Civil Codes of Ukraine but also in all regulatory acts. Moreover, the use of this term will not cause troubles for translators. Considering the above, the terms used in current Ukrainian legislation should be changed.

Titles of Articles 22-23 of the Civil Code of Ukraine make the content of the set rules narrower. Because Article 22 of the abovementioned regulatory act entitles a person to receive compensation for property damages, stipulates its nature and amount, and contains the provisions defining the following civil law terms: "реальні збитки" (Eng.: "actual losses"), "упущена вигода" (Eng.: "expectation damages") Article 23 of the Civil Code of Ukraine establishes the right to compensation for emotional damages, describes what are emotional damages, specifies the procedure for, the amount and forms of compensation. Hence, both articles of the Civil Code of Ukraine should be amended to read as follows: 


"Article 22. Property Damages and
Compensation for Them";
"Article 23. Emotional Damages and
Compensation for Them".

Second, the point is that some of ways to defend family rights and interests are independent and should take their own places in different clauses of the law (separately) to serve the needs of lawapplying practices. First of all, it is not a good idea to incorporate two ways of defending family rights and interests being different by their legislative purposes (the termination of legal relationship and the cancellation of legal relationship) in the same Clause 3, Part 2, Article 18 of the Family Code of Ukraine. Because when we speak about the first way used to defend family rights and interest, we deal with the termination (e.g., the marriage dissolution in accordance with a court decision which deprives spouses of their marital status upon its entry into force) of family relations that arose in fact, i.e. legally. In contrast to the termination of family relations, the cancellation of family relations means breaking off relations that could not legally exist because they arose in contradiction to the law. Such a way of defence of family rights and interests applies through:

finding a marriage invalid;

cancelling the registration as a father or a mother; finding adoption invalid;

finding a certain family law agreement (here we refer not only marital agreements) invalid.

On this occasion, we would like to underline that mentioning the cancellation of legal relations as the way to defend family rights and interests in Clause 3, Part 2, Article 18 of the Family Code of Ukraine made it no longer necessary for judges to refer to Clause 2, Part 2, Article 16 of the Civil Code of Ukraine according to which finding legal relations invalid is the way to defend civil rights and interests.

Two ways to defend civil rights and interests including:

the compensation for property damages;

the compensation for emotional damages should be included to separate clauses of Paragraph 2, Part 2, Article 18 of the Family Code of Ukraine.

Because the first group of provisions of the Family Code of Ukraine specifies reasons for the compensation for property damages only (Article 31; Part 9, Article 177), and the second group of provisions of the Family Code of Ukraine sets forth reasons for the compensation for emotional damages only (Part 2, Article 49; Part 2, Article 50 of the Family Code of Ukraine). The third group of family law provisions stipulates reasons for the compensation for both property and emotional damages (Paragraph 2, Part 4, Article 157; Part 2, Article 158; Part 5, Article 159; Part 2, Article 162 of the Family Code of Ukraine). In addition, it seems acceptable to place such ways of defending rights and interests to different structural elements of the article, inter alia: in Clauses 8 (compensations for property damages) and 9 (compensations for emotional (nonproperty) damages) of Part 2, Article 16 of the Civil Code of Ukraine. On this occasion, it is worth mentioning that the approach offered by the author in no way prevents the use of the abovementioned ways of defending family rights and interests "in tandem" if a certain legal case so requires. Should this be the case, a person at law will in one case refer to a respective part and one respective clause of a relevant article in the law (for example, to the compensation as the way to defend family rights and interests), and in the other case - to a respective part and two respective clauses of a relevant article in the law (to both the compensation for property damages and the compensation for emotional damages as the ways to defend family rights and interests).

Provisions of Paragraph 2, Clause 6, Part 2, Article 18 of the Family Code of Ukraine, are imperfect not only due to terminological errors. The Order of the Supreme Court dated 21 April 2021 says that the restriction of the right of a party to family relations to the compensation for emotional damages by cases specified in Clause 6, Part 2, Article 18 of the Family Code of Ukraine significantly narrows their right to defence and may not be deemed as consistent with justice, good faith, reasonableness which are the general principles of civil and family legislation. Moreover, this document (made by the highest judicial body in the Ukrainian judicial system) states that the cases expressly stipulated by legislators (there are six of them) must be considered as the list of actions causing emotional damages indeed. Finally, the Supreme Court concluded that despite the possibility to receive the compensation for damages in cases described in Articles 49-50, 157-159, 162 of the Family Code of Ukraine, such a way to defend family rights and interests provides grounds for using it also in other cases when the rights of parties to family relations are infringed (Order No. 2-3897/10, 2021).

The abovementioned arguments of the highest judicial institution seem to be convincing. Hence, Paragraph 2, Part 2, Article 18 of the Family 


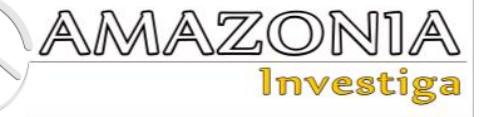

Code of Ukraine should be amended to exclude the following expression: "if it is provided for by this Code or an agreement".

Third, Ukrainian law scholars and philologists should pay their attention at the term "правовідношення" (Eng.: "legal relationship") mentioned among legally established ways of defending family and civil rights and interests. The point is that according to the Ukrainian spelling rules the term "правовідносини" (Eng.: "legal relations") has no singular form and in used in plural only.

Considering the above, the Family Code of Ukraine (namely Paragraph 2, Clauses 1, 3, 5-6, Part 2, Article 18) and the Civil Code of Ukraine (Clauses 7-8, Part 2, Article 16) should be amended by substituting the term "правовідношення" (Eng.: "legal relationship") with the Ukrainian term "правовідносини"(Eng.: "legal relations") used in all cases required.

Fourth, the analysis of Paragraph 2, Part 2, Article 18 of the Family Code of Ukraine allows concluding that in contrast to the Civil Code of Ukraine (Clause 1, Part 2, Article 16), neither original nor amended wording of the abovementioned main instrument for the legal regulation of family relations established or establishes the recognition of a right as the way to defend rights and interests. Because the "catalogue" containing the named ways of defending family rights and interests lacks only the recognition of a right which can be also applied. For example, the recognition of a right will relate to the ways that may be used to defend property rights of one of spouses (a husband or a wife). Therefore, the list of ways to defend the named family rights and interests should be enlarged by incorporating the recognition of a right thereto.

Fifth, the problem is that the ways to defend family rights and interests are placed in illogical sequence in Paragraph 2, Part 2, Article 18 of the Family Code of Ukraine.

Considering the above, Paragraph 2, Part 2, Article 18 of the Family Code of Ukraine should be amended to read as follows:

"The ways of defending family rights and interests are the following:

1) establishing legal relationships;

2) recognising a right;

3) preventing actions which result in violation of family rights;

4) reinstating the legal relationship existing before violation of a right;

5) enforcing the obligation which was not fulfilled voluntarily;

6) changing legal relations;

7) terminating legal relations;

8) cancelling legal relations;

9) granting the compensation for property damages;

10) granting the compensation for emotional damages;

11) finding decisions, actions or omission of a government agency, a government agency of the Autonomous Republic of Crimea or a local government agency, their officials and officers illegal".

There are no Rules without Exceptions or about the Application of the Limitation Period to the Claims Arising Out of Family Relations. Family rights and interests are usually defended regardless of the time that has passed since the violation of a right. Because, pursuant to Part 1, Article 20 of the Family Code of Ukraine, the limitation period is not applied to the claims arising out of family relations. It is obvious that this approach is based on the fact that personal non-property relations prevail in the family law sector and that family relations are long-lasting. Furthermore, the Family Code of Ukraine directly stipulates that the limitation period is not applied to the "trio" of claims:

for the division of property which is an object of matrimonial property law provided that the marriage has not been terminated (Part 1, Article 72);

filed by a husband for the removal the entry of him being a father from the birth record (Part 6, Article 136);

for the removal of the entry of a person being a father from the birth record (Part 4, Article 137).

The exceptions to the rule of non-application of the limitation period in family relations are provided for by:

Part 2, Article 72 (to the claim for the division of property filed after the marriage dissolution);

Part 2, Article 129 (to the claim for acknowledgement of paternity);

Part 3, Article 138 (to the mother's claim for amending her child's birth record);

Part 3, Article 139 (to the claim for acknowledgement of maternity) of the Family Code of Ukraine.

The first case has the limitation period of three years (the longest period of defence of family 
rights and interests) which is counted from the day when one of the co-owners became aware or could have become aware of the violation of their ownership right. In the second, third and fourth cases, the limitation period is one year. It starts on the day when a person became aware or could have become aware of their paternity (in the second exception); a child's birth has been registered (in the third exception); when a person learned or could have learned that she is the child's mother (in the third exception). However, the mentioned "quartet" integrates the fact that the limitation period relating to the claims arising out of family relations usually starts on the day when a person became aware or could have become aware of the violation of their right and interest. Because the limitation period is "like a pike in a lake that keeps a crucian busy" (Romovska, 2020).

It is worth noting that scientific literature sometimes uses a controversial formulation "строк позовної давності" (Eng.: "period of action limitation") (Herasymchuk, 2021). Because the action limitation is the very period meant for defending family rights and interests.

An example of legislators' carelessness rather than a conscious legislative solution is a provision of clause 2-1 which complements Section 7 "Final Provisions" of the Family Code of Ukraine pursuant to the Law of Ukraine "On Amending Certain Legislative Acts of Ukraine Aimed at Ensuring Additional Social and Economic Guarantees in Relation to Spreading of Coronavirus Disease (COVID-19)" dated 30 March 2020 (Law No. 540-IX, 2020). In accordance with the abovementioned legal act, during the quarantine established by the Cabinet of Ministers of Ukraine, in order to prevent the spread of the coronavirus disease (COVID-19), the timeframes set forth in Articles 72, 128, 129, 139 of the Family Code of Ukraine are extended for the period of such a quarantine. The point is that while legislators make it possible to extend the limitation period set forth in Articles 72, 129 and 139 for the period of the quarantine, Article 128 of the Family Code of Ukraine does not allow extending the limitation period. Because the conditions of this article do not specify any period that can be extended by the legislative order. It is obvious that Article 128 of the Family Code of Ukraine was mixed up with Article 138 of the same codified act, Part 3 of which contains one of "quartet" cases when the limitation period applies. Thus, it is expedient to amend Clause 21 of Section 7 "Final Provisions" of the Family Code of Ukraine. It will allow removing the legislative obstacles to extending the limitation period in the case referred to in Part 3, Article 138 of the Family Code of Ukraine.

\section{Conclusions}

Defending family rights and interests in a court is common in Ukraine. However, Ukraine, unlike many other foreign law systems (Australia, Great Britain, Israel, Canada, New Zealand, Singapore, the United States of America, the Federative Republic of Germany, Japan, and "the Family Court" pilot project in Kazakhstan), has no specialized judicial institution that would consider only family matters. That is why it is reasonable to establish a family court and integrate it in the judicial system of Ukraine.

The modernized system of ways of defending family rights and interests must include: establishing legal relationships; recognising a right; preventing actions which result in violation of family rights; reinstating the legal relationship existing before violation of a right; enforcing the obligation which was not fulfilled voluntarily; changing legal relations; terminating legal relations; cancelling legal relations; granting the compensation for property damages; granting the compensation for emotional damages; finding decisions, actions or omission of a government agency, a government agency of the Autonomous Republic of Crimea or a local government agency, their officials and officers illegal. This vision of the system of ways to defend family rights and interests requires updating the family and civil legislation of Ukraine.

The approach set forth in Clause 2-1 of Section 7 "Final Provisions" of the Family Code of Ukraine should be corrected as it makes it impossible to extend the limitation period in the case referred to in Part 3, Article 138 of the Family Code of Ukraine.

\section{Bibliographic references}

Churpita, H. V. (2020). Some Aspects of the Court Protection of Family Rights and Interests. Journal of the National Academy of Legal Sciences of Ukraine, 27(1), pp. 71-83. doi: 10.37635/jnalsu.27(1).2020.71-83

Diakovych, M. M. (2020). Exercising Family Rights and Performing Family Duties. Defending Family Rights and Interests. Scientific and Practical Commentary. Family Code of Ukraine. Kyiv: Yurinkom Inter, pp. 21-29. [in ukrainian]

Herasymchuk, L. (2021). Application of the statute of limitations to family legal relations. 


\section{AMAZONIA
1nvestiga}

Entrepreneurship, Economy and Law, 6, pp. 11-15. [in ukrainian]

Huz, L. Ye., \& Huz, A. V. (2011). Judicial and Practical Commentary to Family Code of Ukraine. Kharkiv: Factor. [in ukrainian]

Krasytska, L.V. (2015). Problems of Execution and Protection of the Personal and Property Rights of Parents and Children (Doctoral thesis), National Prosecution Academy of Ukraine, Kyiv. [in ukrainian]

Law No. 540-IX. On Amending Certain Legislative Acts of Ukraine Aimed at Ensuring Additional Social and Economic Guarantees in Relation to Spreading of Coronavirus Disease (COVID-19), Bulletin of the Verkhovna Rada of Ukraine, Kyiv, Ukraine, March 30, 2020. Recovered from https://zakon.rada.gov.ua/laws/show/54020\#n105

Law No. 1618-IV. Civil Procedure Code of Ukraine, Bulletin of the Verkhovna Rada of Ukraine, Kyiv, Ukraine, March 18, 2004. Recovered from https://zakon.rada.gov.ua/laws/show/161815\#Text

Law No. 254א/96-BP. Constitution of Ukraine, Bulletin of the Verkhovna Rada of Ukraine, Kyiv, Ukraine, June 28, 1996. Recovered from

https://zakon.rada.gov.ua/laws/show/254\%D 0\%BA/96-\%D0\%B2\%D1\%80\#Text

Law No. 2947-III. Family Code of Ukraine. Bulletin of the Verkhovna Rada of Ukraine, Kyiv, Ukraine, January 10, 2002. Recovered from https://zakon.rada.gov.ua/laws/show/294714\#Text

Law No. 435-IV. Civil Code of Ukraine. Bulletin of the Verkhovna Rada of Ukraine, Kyiv, Ukraine, January 16, 2003. Recovered from

https://zakon.rada.gov.ua/laws/show/43515\#n1220

Law No. 524-V. On Amendments to Family and Civil Codes of Ukraine, Bulletin of the Verkhovna Rada of Ukraine, Kyiv, Ukraine, December 22, 2006. Recovered from https://zakon.rada.gov.ua/laws/show/52416\#Text

Matvieieva, L., Baltadzhy, P., Shmalenko, I., Yeftieni, N., \& Ivanchenko, O. (2021). Proteccion legal de grupos de poblacion vulnerables: practica del Tribunal Europeo de Derechos Humanos. Cuestiones Políticas, 39(68), pp. 136-152 https://produccioncientificaluz.org/index.php /cuestiones/article/view/35403

Order No. 2-3897/10. Order of the Supreme Court, Unified State Register of Judicial Decisions, Ukraine, April 21, 2021. Recovered from https://reyestr.court.gov.ua/Review/9649838 7

Romovska, Z. V. (2009). Ukrainian Family Law: Academic Course. Kyiv: Pravova Yednist'.500 p

Romovska, Z. V. (2020). Ukrainian Civil Law. Contract Law: Academic Course. Lviv: PAIS. 464 p.

Serdechna, I (2019). Jurisdictional Form of Protection of Family Rights and Interests. University Scientific Notes, 71 (3), pp. 170-183. doi: 10.37491/UNZ.71.14

Stefanchuk, M., Hladun, O., \& Stefanchuk, R. (2021a). Establishing Trust in the Court in Ukraine as a Strategic Task for Judicial Reform. Access to Justice in Eastern Europe, 3(11), pp. 101-116. doi: 10.33327/AJEE-184.3-n000073

Stefanchuk, M., Hladun, O., \& Stefanchuk, R. (2021b). The right of access to a court in Ukraine in the light of the requirements of the Convention on Protection human rights and fundamental freedoms. Access to Justice in Eastern Europe, 1(9), pp. 186-198. doi: 10.33327/AJEE-18-4.1-n000052

Truba, V. I. (2021). The concept and general classification of family relationships. (Doctoral thesis), V. N. Karazin Kharkiv National University, Kharkiv, 34 p.

Zhylinkova, I. V. (2008). Scientific and Practical Commentary. Family Code of Ukraine. Kharkiv: Xylon, 855 p. 